\title{
Intermediary Metabolite Levels in Escherichia coli
}

\author{
By V. MOSES* AND PAMELA B. SHARP \\ Laboratory of Chemical Biodynamics and Lawrence Radiation Laboratory, \\ University of California, Berkeley, California, 94720, U.S.A.
}

(Accepted for publication 22 January 1972)

\begin{abstract}
SUMMARY
The intra- and extracellular concentrations of a number of phosphorylated intermediary metabolites in Escherichia coli were measured radiochemically during growth in low phosphate $(0.75 \mathrm{~mm})$ media containing $\left[{ }^{32} \mathrm{P}\right] \mathrm{P}_{\mathrm{i}}$. Distribution studies showed that most of the monophosphate metabolites were present in the supernatant medium outside the bacteria. This was much less marked for the di- and triphosphates, and was not due to bacterium lysis. Adenosine $3^{\prime}, 5^{\prime}$-cyclic monophosphate was present solely in the medium under all conditions tested. $3^{\prime}, 5^{\prime}$-CyclicAMP added to the medium was only partly effective in reversing repression of $\beta$-galactosidase synthesis by gluconate. This was not due to degradation of the nucleotide.

In another series of strains, chemical determinations were made of the intraand extracellular concentrations of fructose 1,6 -diphosphate and triose phosphate under varying conditions of growth in high phosphate (O.I M) media; while most of the fructose I,6-diphosphate remained inside the bacteria, triose phosphate was present largely in the medium. In all of these studies there was no correlation between the severity of catabolite repression and the concentrations of metabolites either inside the bacteria, or in the medium.
\end{abstract}

\section{INTRODUCTION}

Studies of the soluble-protein profiles of Escherichia coli have shown marked differences in phenotype as a function of growth in different media (Moses \& Wild, I969; Moses \& Sharp, 1970). The relationship of such phenotypic differences to the cellular levels of intermediary metabolites appeared to be of interest, and preliminary experiments, using shortterm labelling of bacteria with $\left[{ }^{32} \mathrm{P}\right] \mathrm{P}_{\mathrm{i}}$, have already been presented; these included the effects of adding adenosine $3^{\prime}, 5^{\prime}$-cyclic monophosphate to the medium (Moses \& Sharp, I970).

We have extended these measurements of metabolite levels to bacteria grown in minimal medium supplemented with one of five carbohydrates. In each case, we have determined the intra- and extracellular concentrations of a number of substances, using, for technical reasons, long-term labelling of the bacteria with ${ }^{32} \mathrm{P}$, and thereby restricting our observations to phosphorylated compounds. Makman \& Sutherland (1965) reported that the intracellular concentration of $3^{\prime}, 5^{\prime}$-cyclic-AMP varies under different physiological conditions, and that the presence of glucose in the medium prompts the export of the nucleotide from the cells. One of the objects of the present study was to clarify the significance of this export phenomenon by determining the distribution between the bacteria and the medium of a wider range of intermediates, and with a variety of growth substrates.

* Present address: Department of Plant Biology and Microbiology, Queen Mary College, London, E I 4 NS. 


\section{METHODS}

Bacterial strains. Escherichia coli strains 3000, LAI2G and B were from Dr E. Steers, Dr W. F. Loomis, Jun., and Dr M. R. Lunt, respectively. Strain vPI9 has previously been described (Moses \& Sharp, 1970).

Growth conditions and media. The standard minimal medium was M63 (Pardee \& Prestidge, I96I) supplemented with thiamine (I $\mathrm{mg} / \mathrm{l}$ ), and containing the appropriate carbon source at $0.8 \mathrm{mg}$ carbon $/ \mathrm{ml}$. For experiments using $\left[{ }^{32} \mathrm{P}\right] \mathrm{P}_{\mathbf{i}}$, a low-phosphate $\left(0.75 \mathrm{~mm}-\mathrm{P}_{\mathbf{i}}\right)$ minimal medium (LP medium) was employed (Prevost \& Moses, 1967) containing carbon sources as desired. Bacteria in liquid culture were grown as described by Moses \& Prevost (1966).

Induction and assay of $\beta$-galactosidase. These were performed by previously established methods (Palmer \& Moses, I968). One enzyme unit is defined as that quantity giving rise to I nmol of product $/ \mathrm{min}$ at $37^{\circ} \mathrm{C}$.

Intermediary metabolite concentrations. (a) Sugar phosphates and nucleotides. Bacteria were grown through several subcultures in LP medium containing the desired carbon source. [ $\left.{ }^{32} \mathrm{P}\right]$ bacteria from an overnight culture were diluted into fresh LP medium containing $\left.{ }^{32} \mathrm{P}\right] \mathrm{P}_{\mathrm{i}}(0.625 \mathrm{mCi} / \mu \mathrm{mol})$ to give a concentration of about II $\mu \mathrm{g}$ bacterial protein $/ \mathrm{ml}$. Samples $(2 \mathrm{ml})$ were vigorously shaken at $37^{\circ} \mathrm{C}$ in air in stoppered tubes (I $\times 125 \mathrm{~mm}$ ), held at an angle to promote maximum agitation. Growth was followed at $650 \mathrm{~nm}$ with a Spectronic 20 spectrophotometer (Bausch \& Lomb, Rochester, New York, U.S.A.) masked to permit reading $2 \mathrm{ml}$ volume of liquid in the tubes. When the bacterium density reached $\mathrm{Ir}_{5} \mu \mathrm{g}$ bacterial protein $/ \mathrm{ml}$, I $\mathrm{ml}$ samples of the suspension were mixed with $4 \mathrm{ml}$ ethanol. In some experiments, samples of the bacterium-free supernatant were also obtained by centrifugation of $0.4 \mathrm{ml}$ of the suspension at room temperature for $5 \mathrm{~min}$ at $15,000 \mathrm{~g}(\max )$ in a Microfuge Model I52A (Beckman Instuments, Inc., Spinco Division, Palo Alto, California, U.S.A.). This instrument reaches full speed, and comes to rest, within $5 \mathrm{~s}$ of being switched on or off. Measured portions of the ethanolic bacterium suspension, and of the supernatant medium, were chromatographed in toto on sheets of Ederol no. 202 paper (J. C. Binzer, G.M.B.H., Hatzfeld/Eder, Germany), with the solvent system described by Crowley, Moses \& Ullrich (1963). Chromatograms were over-run to permit maximum separation of phosphorylated compounds. The labelled components were located on the chromatograms by autoradiography. The spots were excised and the radioactivity measured automatically at known counting efficiency (Moses \& Lonberg-Holm, 1963), or by immersion of the pieces of paper in toluene-based scintillation fluid, followed by counting in a Tri-Carb Liquid Scintillation Spectrometer Model 3375 (Packard Instrument Co., Inc., Downers Grove, Illinois, U.S.A.). Corrections were made for efficiency and for the decay of ${ }^{32} \mathrm{P}$. The concentrations of phosphorylated compounds were then calculated in terms of $\mu \mathrm{mol} \mathrm{P} / \mathrm{g}$ bacterial protein. For spot identifications, authentic marker compounds were chromatographed on parallel chromatograms with the same labelled bacterium extract.

(b) Fructose I,6-diphosphate and triose phosphate. Bacteria in M63 medium containing the desired carbon source were grown exponentially to a measured density of 150 to $200 \mu \mathrm{g}$ bacterial protein $/ \mathrm{ml}$. Samples $(6 \mathrm{ml})$ of the suspension were mixed with $0.66 \mathrm{ml}$ of $50 \%(\mathrm{w} / \mathrm{v})$ trichloroacetic acid. Simultaneously, portions of the culture were filtered through a pad consisting (top to bottom) of one Whatman glass-fibre disc GF/B, one Whatman glass-fibre disc GF/C, and one Millipore filter disc (0.45 $\mu \mathrm{m}$ pore size). The Millipore filter ensured removal of the bacteria, but rapidly clogged unless the glass-fibre discs were present as prefilters. Portions of the filtrate $(6 \mathrm{ml})$ were mixed with $0.66 \mathrm{ml}$ of $50 \%(\mathrm{w} / \mathrm{v})$ trichloroacetic acid. After $\mathrm{I} h$ at room temperature (and after centrifugation for the whole-suspension 
Table I. Growth and enzyme synthesis in strain VP I 9

The bacteria were induced with $0.5 \mathrm{mM}$-IPTG during growth in the media listed. $\beta$-Galactosidase as units/mg protein; growth rates as doublings/h

\begin{tabular}{|c|c|c|c|c|}
\hline \multirow[b]{2}{*}{ Carbon source } & \multicolumn{2}{|c|}{ M63 medium } & \multicolumn{2}{|c|}{ Low $P_{i}$ medium } \\
\hline & $\beta$-Galactosidase & Growth rate & $\beta$-Galactosidase & Growth rate \\
\hline Acetate & II $\cdot 8$ & 0.59 & 12.8 & 0.35 \\
\hline$N$-Acetylglucosamine & $6 \cdot 7$ & 0.92 & - & - \\
\hline Fructose & 10.8 & 0.73 & - & - \\
\hline Galactose & $5 \cdot \mathrm{I}$ & 0.85 & - & - \\
\hline Gluconate & $6 \cdot 2$ & 0.74 & $3 \cdot 4$ & $\mathrm{I} \cdot 05$ \\
\hline Glucose & 3.9 & 0.94 & $3 \cdot 6$ & 1.05 \\
\hline Glucose-6-phosphate & $I \cdot 6$ & $\mathrm{I} \cdot 09$ & - & - \\
\hline Glucose + tryptone & $\mathrm{I} \cdot \mathrm{O}$ & 1.62 & - & - \\
\hline Glycerol & $11 \cdot 9$ & 0.67 & $8 \cdot 5$ & 0.86 \\
\hline Lactate & II. 8 & 0.59 & - & - \\
\hline Lactose & $5 \cdot 3$ & $0.8 \mathrm{I}$ & -- & - \\
\hline Maltose & $7 \cdot I$ & $0.8 \mathrm{I}$ & - & - \\
\hline Ribose & $12 \cdot \mathrm{I}$ & 0.58 & $10 \cdot 2$ & $0.7 \mathrm{I}$ \\
\hline Succinate & 10.4 & 0.72 & - & - \\
\hline
\end{tabular}

samples), the clear solutions were extracted five times with ether to remove trichloroacetic acid, and residual ether was removed with a stream of air. The concentrations of fructose I,6-diphosphate and triose phosphate in the solutions were measured by the method of Bücher \& Hohorst (1965). The concentration of the metabolites within the bacteria was calculated from the difference in concentration between the whole suspension and the filtered medium.

Chemicals and radiochemicals. Carrier-free $\left[{ }^{32} \mathrm{P}\right] \mathrm{P}_{\mathrm{i}}$ was obtained from International Chemical and Nuclear Corporation, Irvine, California U.S.A. $\left[8{ }^{-14} \mathrm{C}\right]$ Adenosine- $3^{\prime}, 5^{\prime}$-cyclic monophosphate was purchased from New England Nuclear Corporation, Boston, Massachusetts, U.S.A.; 3',5'-cyclic-AMP from Calbiochem, Los Angeles, California, U.S.A.; dihydroxyacetone phosphate, glyceraldehyde 3-phosphate and $\mathrm{NADP}^{+}$from Sigma Chemical Co., St Louis, Missouri, U.S.A.; and isopropyl-thio- $\beta$-D-galactoside (IPTG) from Cyclo Chemical Corporation, Los Angeles, California, U.S.A.

Enzymes for the assay of fructose I,6-diphosphate and triose phosphate, rabbit muscle ketose I-phosphate aldehyde lyase (EC. 4.I.2.7), yeast D-glyceraldehyde 3-phosphate: NAD oxidoreductase (EC. I.2.I.I2), and rabbit muscle D-glyceraldehyde 3-phosphate ketol-isomerase (EC. 5.3.I.I), were purchased from Boehringer Mannheim Corporation, San Francisco, California, U.S.A.

\section{RESULTS}

Intermediary metabolite concentrations. The rates of growth, and of induced $\beta$-galactosidase synthesis, in strain VPI9 growing in a variety of media are shown in Table I.

The intra- and extracellular concentrations of a number of phosphorylated intermediates in this strain, growing exponentially in LP medium on each of five carbon sources, are given in Table 2. The experimental data were obtained as counts of ${ }^{32} \mathrm{P} / \mathrm{min} / \mathrm{ml}$ of cell suspension of known $E_{650}$. The specific radioactivity of the ${ }^{32} \mathrm{P}$ was known. The intra- and extracellular concentrations were then calculated by means of the following assumptions: (i) at $E_{650}=\mathrm{I} \cdot 0$, I $\mathrm{ml}$ of cell suspension contains $225 \mu \mathrm{g}$ bacterial protein (Moses \& Prevost, I966); (ii) protein constitutes $56 \%(\mathrm{w} / \mathrm{v})$ of the bacterial dry wt (Roberts et al. 1955); (iii) the density 


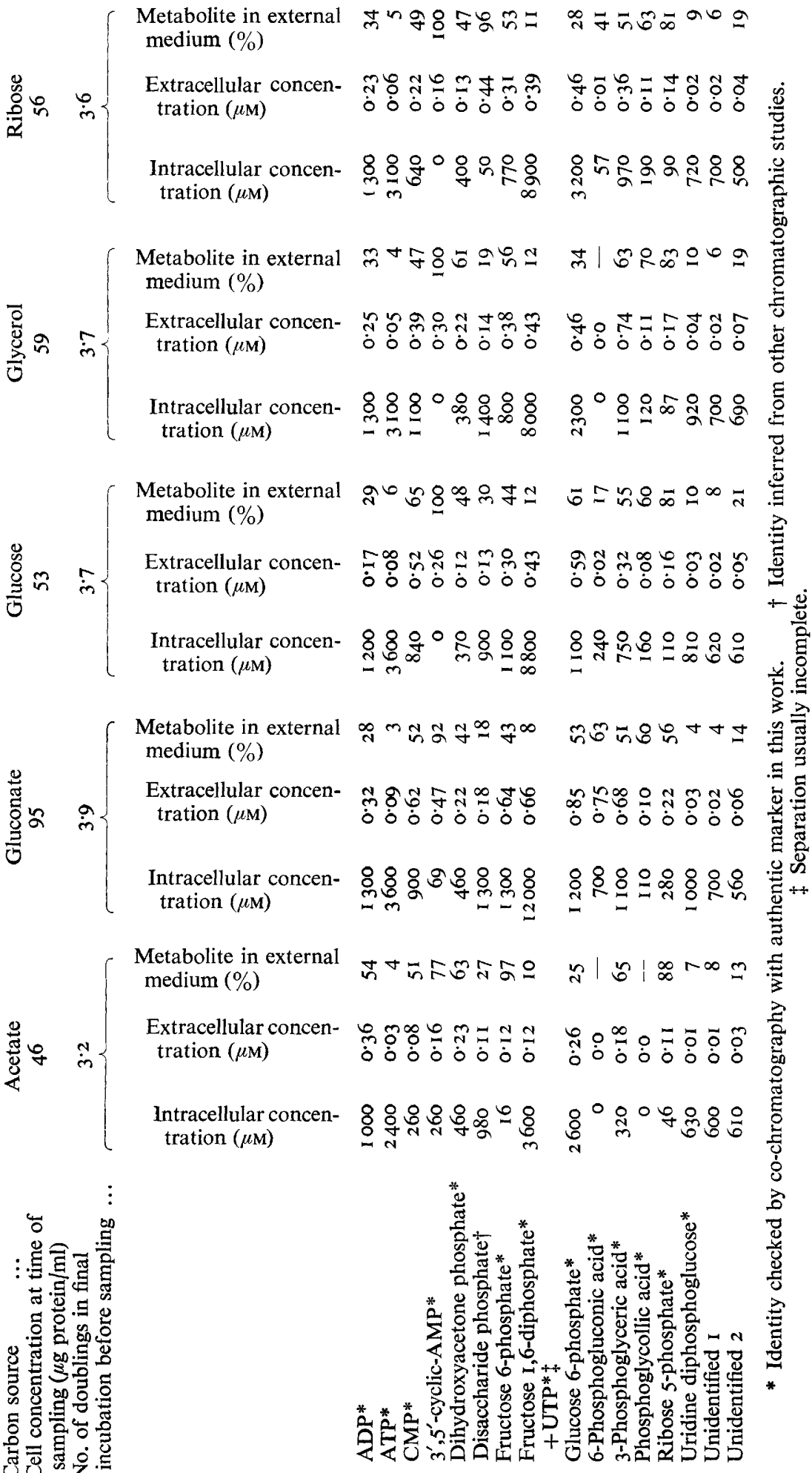




\section{Table 3. Sedimentation of strain VPI9}

Exponentially growing cultures in LP medium, or M63, plus gluconate, were sedimented by centrifugation for $5 \mathrm{~min}$ at $37^{\circ} \mathrm{C}$ in the Microfuge. Samples of the total suspension, and of the supernatant medium, were used for measurement of visible bacteria, and for total protein by the method of Lowry, Rosebrough, Farr \& Randall (I95I). Total protein could not be measured in this way in $\mathrm{MG}_{3}$; there appeared to be interference by the high concentration of $\mathrm{K}^{+}$.

Percentage of bacteria sedimented
(a) from LP medium + gluconate
(b) from M63+gluconate

Percentage of total protein sedimented

(a) from LP medium + gluconate
VP19

$98 \cdot 5$

$98 \cdot 1$

$97 \cdot 5$

\section{Table 4. Intra- and extracellular concentrations of fructose 1,6-diphosphate and triose phosphate in strain 3000}

For bacteria during exponential growth in the media indicated, separate determinations were made of the total and extracellular concentrations, from which intracellular concentrations were calculated on the basis of the assumptions defined in the text. $\mathrm{N}$-starved bacteria were prepared by washing and suspending bacteria from an exponential culture in $\mathrm{M} 63$ without $\mathrm{NH}_{4} \mathrm{Cl}$. After 15 min at $37^{\circ} \mathrm{C}$, the bacteria were washed again and incubated for 45 minat $37^{\circ} \mathrm{C}$ in $\mathrm{M} 63$ devoid of both $\mathrm{NH}_{4} \mathrm{Cl}$ and the carbon source. A carbon source $(0.2 \%, \mathrm{w} / \mathrm{v})$ and $0.5 \mathrm{~mm}$-IPTG were then added. During the following $30 \mathrm{~min}$ at $37^{\circ} \mathrm{C}$ samples were taken periodically for $\beta$-galactosidase assays, after which further samples were removed for determination of the intra- and extracellular metabolite concn. Relative rates of $\beta$-galactosidase synthesis for the exponential cultures are expressed in arbitrary units/unit of bacterial protein synthesized. For N-starved cells, enzyme synthesis is reported as relative activity after $30 \mathrm{~min}$ induction/unit of bacterial protein present. Metabolite concentrations are expressed in terms of $\mathbf{P}$.

Fructose I,6-diphosphate

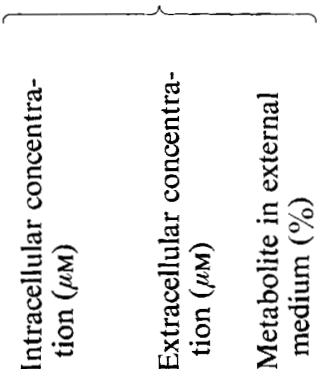

Carbon source

Exponential bacteria

$\begin{array}{lcccc}\text { Glucose } & 3900 & 0.0 & 0 & 830 \\ \begin{array}{l}\text { Glucose }+ \\ \text { casein }\end{array} & 3800 & 0.98 & 14 & 220 \\ \text { hydrolysate } & & & & \\ \begin{array}{l}\text { Glycerol } \\ \text { Glycerol+ }\end{array} & 4700 & 0.44 & 6 & 2400 \\ \text { casein } & 5200 & 0.14 & 2 & 3000 \\ \text { hydrolysate } & & & & \\ \text { Succinate } & 240 & 0.0 & 0 & 500 \\ \text { N-starved bacteria (after growth in succinate) } & \\ \text { None } & 92 & 0.0 & 0 & 380 \\ \text { Glucose } & 3400 & 0.0 & 0 & 1200 \\ \text { Glycerol } & 6000 & 0.0 & 0 & 2200 \\ \text { Succinate } & 1100 & 0.0 & 0 & 900\end{array}$

Triose phosphate
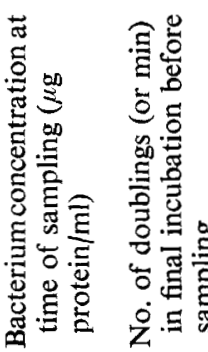

Doublings

$830 \quad 1 \cdot 5$

$2 \cdot 3$

57
86

52

220

247

$2 \cdot 0$

$1 \cdot 9$

2400

$$
3 \cdot I
$$

$2 \cdot 5$

46

38

100

236

$3 \cdot 3$

IOI

215

$3 \cdot 0$

\begin{tabular}{l}
$500 \quad 3.7 \quad 80$ \\
\hline
\end{tabular}

100

268

I 8

Min

$380 \quad 0.14 \quad 20$

200

$2 \cdot 7$

$3 \cdot 7$

$2 \cdot \mathrm{I}$ 
Table 5. Intra- and extracellular concentrations of fructose 1,6-diphosphate and triose phosphate in strain $\mathrm{B}$

Experimental details as in Table 2

Fructose I,6-diphosphate
$\underbrace{2}$

of living bacterial cells is I.I (Ruffilli, I933); (iv) the dry wt of bacterial cells is $20 \%$ of the wet wt (Porter, 1946); (v) the whole of the aqueous phase of the bacteria is accessible to the metabolites. Replication of this experiment showed that for most compounds the concentration was reproducible to within about $\pm 10 \%$.

The appearance of large amounts of monophosphate metabolites in the medium seems to have been due to a genuine leakage from the bacteria. Had it been due to bacterial lysis, or a failure to obtain samples of the supernatant medium free from bacteria, the diphosphates and triphosphates should have been similarly distributed between bacteria and medium. Table 3 shows that 5 min of centrifugation in the Microfuge was sufficient to sediment more than $97 \%$ both of the visible bacteria and of the total protein.

Leakage of the monophosphates into the medium was not the result of growth in LP medium, or in the presence of $\left[{ }^{32} \mathrm{P}\right] \mathrm{P}_{\mathbf{i}}$. This medium was necessary for measurements using $\left.{ }^{32} \mathrm{P}\right] \mathrm{P}_{\mathrm{i}}$ in order to achieve a suitably high specific radioactivity in the metabolic products, while at the same time avoiding levels of radiation hazardous both to the bacteria and to the experimenters. Chemical determinations of the intra- and extracellular concentrations of fructose 1,6-diphosphate and triose phosphate, in bacteria growing in high $\mathrm{P}_{\mathbf{i}}$ (O.I M) medium, showed again the leakage of the monophosphates but not of the diphosphate (Tables 4 to 6).

$3^{\prime}, 5^{\prime}$-Cyclic-AMP. The data in Table 2 indicate that $3^{\prime}, 5^{\prime}$-cyclic-AMP was present entirely in the medium with all growth substrates tested. We therefore investigated the uptake of 
Table 6. Intra- and extracellular concentration of fructose

I,6-diphosphate and triose phosphate in strain LAI2G

Experimental details as in Table 2

\begin{tabular}{|c|c|c|c|c|c|c|c|c|c|}
\hline \multirow[b]{2}{*}{ Carbon source } & \multicolumn{3}{|c|}{ Fructose 1,6-diphosphate } & \multicolumn{3}{|c|}{ Triose phosphate } & \multirow[b]{2}{*}{ 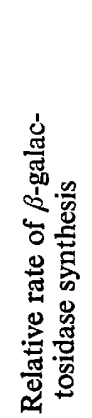 } & \multirow[b]{2}{*}{ 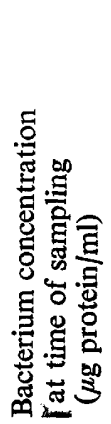 } & \multirow[b]{2}{*}{ 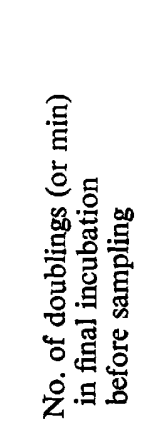 } \\
\hline & 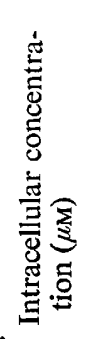 & 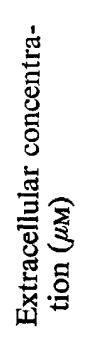 & 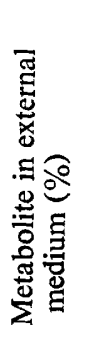 & 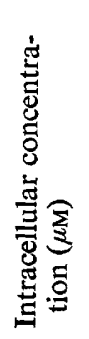 & 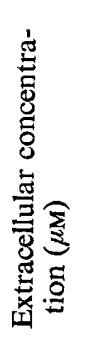 & 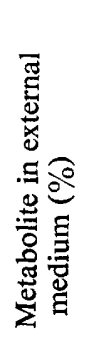 & & & \\
\hline \multicolumn{9}{|c|}{ Exponential bacteria } & Doublings \\
\hline Glucose & 3800 & $2 \cdot 0$ & 22 & 720 & $3 \cdot I$ & 70 & 63 & 277 & $2 \cdot 3$ \\
\hline $\begin{array}{l}\text { Glucose }+ \\
\text { casein } \\
\text { hydrolysate }\end{array}$ & 2400 & $2 \cdot 3$ & 35 & 770 & $1 \cdot 6$ & 54 & 55 & 264 & $2 \cdot 1$ \\
\hline Glycerol & 2900 & 0.0 & 0 & 1900 & $4 \cdot 5$ & 59 & 100 & 254 & $2 \cdot 2$ \\
\hline $\begin{array}{l}\text { Glycerol + } \\
\text { casein } \\
\text { hydrolysate }\end{array}$ & 2000 & 0.71 & 16 & 1400 & $\mathrm{I} \cdot 8$ & 42 & 55 & 275 & $2 \cdot 6$ \\
\hline Lactate & 0 & $0 \cdot 0$ & - & 0 & I. 5 & 100 & 100 & 228 & $\mathrm{I} \cdot 8$ \\
\hline \multicolumn{7}{|c|}{$\mathrm{N}$-starved cells (after growth in lactate) } & & & $\min$ \\
\hline None & 430 & 0.0 & 0 & 0 & 0.14 & 100 & 100 & $15 \mathrm{I}$ & 40 \\
\hline Glucose & 5200 & $2 \cdot 4$ & $3 \mathrm{I}$ & 1300 & $3 \cdot 2$ & $7 \mathrm{I}$ & 4 & I5I & 40 \\
\hline Glycerol & 1600 & 0.0 & 0 & 0 & 0.0 & - & o & I5I & 40 \\
\hline Lactate & 130 & 0.0 & 0 & 0 & 0.28 & 100 & 4 & I5I & 40 \\
\hline
\end{tabular}

Table 7. Effect of $3^{\prime}, 5^{\prime}$-cyclic-AMP on growth and $\beta$-galactosidase synthesis

Strain VPI 9 was grown exponentially in LP me diumcontaining ribose or gluconate. $\beta$-Galactosidase was induced with $0.5 \mathrm{~mm}$-IPTG. The rates of growth and of $\beta$-galactosidase synthesis were measured in the presence of two concentrations of $3^{\prime}, 5^{\prime}$-cyclic-AMP.

\begin{tabular}{|c|c|c|c|}
\hline Carbon source & $\begin{array}{l}\text { Concentration of } \\
3^{\prime}, 5^{\prime} \text {-cyclic-AMP' } \\
\text { (M) }\end{array}$ & $\begin{array}{l}\text { Growth rate } \\
\text { (doublings } / \mathrm{h} \text { ) }\end{array}$ & $\begin{array}{l}\beta \text {-Galactosidase } \\
\text { synthesis (units/mg } \\
\text { bacterial protein) }\end{array}$ \\
\hline $\begin{array}{l}\text { Ribose } \\
\text { Ribose } \\
\text { Ribose }\end{array}$ & $\begin{array}{l}0 \\
10^{-5} \\
10^{-3}\end{array}$ & $\begin{array}{l}0.69 \\
0.68 \\
0.65\end{array}$ & $\begin{array}{l}8500 \\
8600 \\
9100\end{array}$ \\
\hline $\begin{array}{l}\text { Gluconate } \\
\text { Gluconate }\end{array}$ & $\begin{array}{c}0 \\
10^{-5} \\
10^{-3}\end{array}$ & $\begin{array}{l}0.93 \\
0.93 \\
0.77\end{array}$ & $\begin{array}{l}3200 \\
3000 \\
4500\end{array}$ \\
\hline
\end{tabular}

the nucleotide, its further metabolism, and its effect on growth and $\beta$-galactosidase synthesis. At a concentration of I mM, neither growth nor the rate of enzyme synthesis was affected in ribose medium, while the growth rate and catabolite repression were reduced in bacteria growing in gluconate medium (Table 7). In both media, at $10^{-5} \mathrm{M}$, and $10^{-3} \mathrm{M}$, added $\left[8{ }^{14} \mathrm{C}\right] 3^{\prime}, 5^{\prime}$-cyclic-AMP was recovered entirely from the medium (100.5\% in ribose, and $99.0 \%$ in gluconate). No soluble metabolic products were observed chromatographically, and the incorporation of ${ }^{14} \mathrm{C}$ into insoluble material corresponded to rates of nucleotide metabolism of 0.40 and $0.075 \mathrm{nmol} / \mathrm{mg}$ bacterial protein synthesized, for bacteria in ribose 
and glutonate, respectively. Other studies, with Escherichia coli strain 3000 , have confirmed these results, and showed that with I mM $3^{\prime}, 5^{\prime}$-cyclic-AMP added to the medium, the intracellular concentration was but slightly higher than that in the medium (V. Moses \& J. Mowbray, unpublished work). Since, in the present experiments, intact bacteria constituted about $0.1 \%$ of the total volume of the suspension, these results are consistent with only the observations that, within experimental error, essentially all of the $3^{\prime}, 5^{\prime}$-cyclic-AMP formed endogenously leaks to the medium.

\section{DISCUSSION}

In measurements of the distribution of metabolites between the bacteria and the medium, it was found with all media that a considerable fraction of the monophosphorylated substances appeared in the medium. Nevertheless, in almost every case the concentration remained considerably higher inside the bacteria. Sincel the bacteria constituted only about $0.1 \%$ of the total bulk of the suspension, the intracellular concentration would exceed the extracellular unless more than $99.9 \%$ of the substance was outside the bacteria. Our techniques were not sufficiently precise to permit such evaluations. We have not distinguished experimentally between metabolites actually within the bacteria and those, if there are any, absorbed on to the surface membrane or wall. This distinction does not greatly affect the conclusions if one considers simply two general pools of metabolites, one directly associated with the bacteria, and the other in the medium.

Several trivial explanations might account for the presence of these compounds in the medium: a sizeable proportion of the bacteria in the culture lysed and released their contents; the bacteria were not completely removed from the medium before the latter was sampled; leakage was promoted by growth in low phosphate medium, or by the presence of ${ }^{32} \mathrm{P}$. Lysis would be expected to release not only monophosphates, but also diphosphates, triphosphates and protein. It has been found (V. Moses, unpublished work), that Escherichia coli will not use fructose 1,6-diphosphate and ATP as sole sources of carbon unless the $P_{i}$ concentration is low enough (less than $0.025 \mathrm{mM}$ ) to permit derepression of alkaline phosphatase; monophosphates, such as glucose 6-phosphate, are utilized as carbon sources in the presence of $\mathbf{P}_{\mathbf{i}}$. There is, as a result, no reason to believe that had di- and triphosphates, as well as monophosphates, been released, they would have been preferentially utilized and thus not been observed in the extracellular medium. Failure to remove bacteria from the medium would similarly not specifically have favoured the presence of the monophosphates in the supernatant medium. It is clear from Table 2, however, that the monophosphates were preferentially released, and from Table 3 that both bacteria and cellular protein were adequately sedimented. Leakage appeared not to be the result specifically of growth in low phosphate medium, or in the presence of ${ }^{32} \mathrm{P}$, since it was also observed in limited studies in high phosphate medium in the absence of radioactivity (Tables 4 to 6). The leakage of some metabolites to the medium thus appears to be a genuine aspect of cell physiology.

We have not, to date, made kinetic measurements of the rate of leakage. The results reported in Table 2 were obtained with cultures at similar densities, although the bacteria were growing at different rates. The bacteria were thus resident in the incubation media for varying periods, and the accumulation of extracellular metabolites may have proceeded at different rates. There was, however, no clear pattern of greater accumulation in the more slowly growing cultures.

Correlation has not been obtained between the degree of catabolite repression and the concentration, either inside or outside the bacteria, of the metabolites studied. Of particular interest are the observations that in all carbon sources, $3^{\prime}, 5^{\prime}$-cyclic-AMP was entirely, or 
almost entirely, restricted to the medium. This nucleotide has been implicated as one of the essential factors in the synthesis of inducible enzymes subject to catabolite repression (de Crombrugghe, Perlman, Varmus \& Pastan, 1969).

Makman \& Sutherland (1965) reported that the intracellular concentration of $3^{\prime}, 5^{\prime}$-cyclicAMP declined in the presence of glucose, and that this decline was a consequence of its excretion into the medium when glucose was present. From their report has arisen the hypothesis that the severity of catabolite repression is linked to the intracellular level of $3^{\prime}, 5^{\prime}$-cyclic-AMP. Close examination of the published results leads one to doubt their validity. The criticisms of their work may be summarized as follows: $(a)$ bacteria for analysis were harvested by centrifugation at room temperature for $15 \mathrm{~min}$; they were not washed. No estimate could be made of changes in $3^{\prime}, 5^{\prime}$-cyclic-AMP concentration during this procedure, nor of how much might have been contained in the interstitial water; (b) they used non-growing bacteria in buffer containing a carbon source, but no nitrogen. It is not clear to us how to relate growing and nitrogen-starved bacteria; $(c)$ the intracellular concentration of $3^{\prime}, 5^{\prime}$-cyclic-AMP during growth was reported to rise when glucose in the medium was exhausted. However, the total growth observed was less than one doubling, and the evidence actually presented suggests that the concentration of the nucleotide began to rise when nearly $50 \%$ of the initial glucose remained. The residual glucose at that time was quite"sufficient to support maximal exponential growth (Monod, I942); $(d)$ the measured amount of $3^{\prime}, 5^{\prime}$-cyclic-AMP appearing in the medium when glucose was supplied to bacteria in buffer was $\mathrm{I} \cdot 5$ to 7.5 times the measured quantity lost from the bacteria; $(e)$ it was reported that considerable amounts of other ribose-containing nucleotides appeared in the medium,' but these were not identified; $(f)$ although Makman \& Sutherland (1965) used Crooke's strain of Escherichia coli, while we have used a derivative of $\mathrm{KI} 2$, we have thought it useful to compare their data for the intracellular concentration of $3^{\prime}, 5^{\prime}$-cyclic-AMP with bacteria in different carbon sources with our own data on growth rates and differential rates of $\beta$-galactosidase synthesis in those same carbon sources (Table I). We have not found correlation.

The distribution of phosphorylated esters between the bacteria and the medium appears to be a controlled process, since not all substances leak in the same proportion. We suggest that the controlled leakage may have a homeostatic function for the culture as a whole, in which substances, possibly including $3^{\prime}, 5^{\prime}$-cyclic-AMP, play a role in regulating the growth and physiology of the culture in a manner analogous to that of hormones in animal systems. It is not without interest that Okabayashi, Ide \& Yoshimoto (I963) and Okabayashi, Yoshimoto \& Ide (1963) have observed the presence of $3^{\prime}, 5^{\prime}$-cyclic-AMP in the medium of Brevibacterium liquefaciens cultures.

This work was sponsored by the U.S. Atomic Energy Commission. We thank those who kindly supplied us with bacterial strains and with chemicals. We acknowledge with pleasure many stimulating discussions with Dr M. D. Yudkin. Some of this work was performed in the Microbiology Unit, Department of Biochemistry, University of Oxford, during the tenure by V.M. of a Guggenheim Memorial Fellowship. We thank Mrs Pat Sanders for technical assistance during that period. 


\section{REFERENCES}

BÜCHER, T. \& HoHORST, H. J. (1965). Dihydroxyacetone phosphate, fructose-I,6-diphosphate and Dglyceraldehyde-3-phosphate. Determination with glycerol-I-phosphate dehydrogenase, aldolase and triose phosphate dehydrogenase. In Methods of Enzymatic Analysis, 2nd edn, pp. 246-252. Edited by H. U. Bergmeyer. New York and London: Academic Press.

de Crombrugghe, B., Perlman, R. E., Varmus, H. E. \& Pastan, I. (I969). Regulation of inducible enzyme synthesis in Escherichia coli by cyclic adenosine $3^{\prime}, 5^{\prime}$-monophosphate. Journal of Biological Chemistry 244, 5828-5835.

Crowley, G. J., Moses, V. \& Ullrich, J. (I963). A versatile solvent to replace phenol for the paper chromatography of radioactive intermediary metabolites. Journal of Chromatography 12, 219-228.

Lowry, O. H., Rosebrough, N. J., Farr, A. L. \& Randall, R. J. (I95I). Protein measurement with the Folin phenol reagent. Journal of Biological Chemistry 193, 265-275.

MAKman, R. S. \& Sutherland, E. W. (1965). Adenosine 3',5'-phosphate in Escherichia coli. Journal of Biological Chemistry 240, 1309-13I4.

Monod, J. (1942). Recherches sur la croissance des cultures bactériennes. Paris: Hermann.

Moses, V. \& LoNBerG-HoLm, K. K. (1963). A semi-automatic device for measuring radioactivity on twodimensional paper chromatograms. Analytical Biochemistry 5, I I-27.

Moses, V. \& Prevost, C. (1966). Catabolite repression of $\beta$-galactosidase synthesis in Escherichia coli. Biochemical Journal 100, 336-353.

MOSES, V. \& SHARP, P. B. (1970). Adenosine 3',5'-cyclic monophosphate and catabolite repression in Escherichia coli. Biochemical Journal rr8, 481-489.

Moses, V. \& WILD, D. G. (1969). Soluble protein profiles in Escherichia coli. Folia microbiologica 14, 305-309.

OKABAYASHI, T., IDE, M. \& Yoshimoto, A. (1963). Excretion of adenosine- $3^{\prime}, 5^{\prime}$-phosphate in the culture broth of Brevibacterium liquefaciens. Archives of Biochemistry and Biophysics 10o, 158.

OKabaYAShI, T., Yoshimoto, A. \& IDE, M. (1963). Occurrence of nucleotides in culture fluids of microorganisms. V. Excretion of adenosine cyclic $3^{\prime}, 5^{\prime}$-phosphate by Brevibacterium liquefaciens $\mathrm{Sp} . \mathrm{N}$. Journal of Bacteriology 86, 930-936.

PALMER, J. \& Moses, V. (1968). The role of the regulator-gene product (repressor) in catabolite repression of $\beta$-galactosidase synthesis in Escherichia coli. Biochemical Journal 106, 339-343.

Pardee, A. B. \& Prestidge, L. S. (1961). The initial kinetics of enzyme induction. Biochimica et biophysica acta $49,77-88$.

PorTer, J. R. (1946). Bacterial Chemistry and Physiology. New York: John Wiley.

PRevost, C. \& Moses, V. (1967). Pool sizes of metabolic intermediates and their relation to glucose repression of $\beta$-galactosidase synthesis in Escherichia coli. Biochemical Journal 103, 349-357.

Roberts, R. B., Abelson, P. H., Cowie, D. B., Bolton, E. T. \& Britten, R. J. (I955). Studies of Biosynthesis in Escherichia coli. Carnegie Institution Publication 607. Washington, D.C.: Carnegie Institution.

RufFILLI, D. (1933). Studies on the specific gravity of bacteria. Biochemische Zeitschrift 263, 63-74. 